\title{
Pengembangan Media Big Book pada Tema Kewajiban dan Hakku
}

\author{
Noviana Hadi Astuti 1*, Fine Reffiane ${ }^{2}$, Sunan Baedowi ${ }^{3}$ \\ 123Program Studi Pendidikan Guru Sekolah Dasar, Fakultas Ilmu Pendidikan Universitas PGRI Semarang
}

\begin{abstract}
Abstrak
Keywords:

Latar belakang penelitian ini adalah keterbatasan media pembelajaran sehingga minat belajar dan membaca siswa yang rendah membuat guru kesulitan dalam mengajar, sehingga didapatkan hasil bahwa kegiatan belajar mengajar di kelas Pengembangan, Big Book, kewajiban dan hakku menjadi kurang kondusif. Rumusan masalah dalam penelitian ini adalah "Bagaimanakah media Big Book yang valid digunakan sebagai media pembelajaran tema Kewajiban dan Hakku subtema Kewajiban dan Hakku sebagai Warga Negara kelas III SD?" dan "Bagaimanakah media Big Book yang praktis digunakan sebagai media pembelajaran tema Kewajiban dan Hakku subtema Kewajiban dan Hakku sebagai Warga Negara kelas III SD?”Jenis penilitian yang digunakan oleh peneliti adalah penelitian dan pengembangan (Research and Development). Penelitian ini dilakukan di SDN Peterongan Kota Semarang pada tiga kelas yaitu kelas IIIA,IIIB, dan IIIC. Hasil uji kevalidan diperoleh berdasarkan penilaian dari ahli media sebesar 91,34\% dengan kriteria "sangat baik" dan dari skor rata-rata presentase keidealan ahli materi sebesar 92,80\% dengan kriteria "sangat baik". Sedangkan hasil uji kepraktisan diperoleh berdasarkan penilaian respon guru dan siswa dengan skor rata-rata respon guru sebesar 88,6\% dengan kategori "sangat baik" dan skor rata-rata respon siswa sebesar 99,2\% dengan kategori "sangat baik". Kesimpulannya bahwa media Big Book valid dan praktis digunakan untuk siswa kelas III Sekolah Dasar. Kesimpualannya, media Big Book dapat digunakan sebagai penyempurna penelitian dan sebagai salah satu alternatif guru dalam mengajar siswa kelas III Sekolah Dasar.
\end{abstract}

\section{PENDAHULUAN}

Salah satu cita-cita bangsa Indonesia adalah mencerdaskan kehidupan bangsa. Cita-cita mulia tersebut untuk membawa manusia Indonesia ke dalam suatu keadaan yang dapat meningkatkan sumber daya manusia bangsa Indonesia guna meningkatkan kesejahteraan umum, yang tercantum dalam pembukaan UUD 1945 alinea ke IV. Mencerdaskan kehidupan bangsa merupakan salah satu fungsi dari pendidikan nasional, yang tercantum dalam UU No. 20 tahun 2003 pasal 3, yakni: Pendidikan nasional berfungsi mengembangkan kemampuan dan membentuk watak serta peradaban bangsa yang bermartabat dalam rangka mencerdaskan kehidupan bangsa, bertujuan untuk berkembangnya potensi peserta didik agar menjadi manusia yang beriman dan bertaqwa kepada Tuhan Yang Maha Esa, berakhlak mulia, sehat, berilmu, cakap, kreatif, mandiri, dan menjadi warga negara yang demokratis serta bertanggung jawab.

Dalam rangka peningkatan mutu pendidikan sistem kurikulum pendidikan di Indonesia terus berkembang. Berkembang dari kurikulum sebelumnya yaitu KTSP pemerintah merancang kembali menjadi kurikulum saat ini yaitu kurikulum 2013. Kurikulum dirancang dengan pendekatan scientific (pendekatan dengan menerapkan karakteristik yang ilmiah) dengan menerapkan model, metode, dan strategi pembelajaran. Pada kurikulum 2013 menuntut siswa untuk aktif dan kreaftif dalam pembelajaran di kelas dengan memberikan kesempatan kepada siswa untuk mengembangkan tiga aspek yaitu aspek sikap (afektif), aspek pengetahuan (kognitif), dan aspek keterampilan (psikomotor).Pada

* Corresponding author.

E-mail Addresses: - noviana.nha@gmail.com (Noviana Hadi Astuti) 
kurikulum 2013 menggunakan sistem pembelajaran pembelajaran tematik yang menggunakan tema untuk mengaitkan beberapa mata pelajaran.

Pembelajaran tematik adalah "pembelajaran terpadu yang menggunakan tema untuk mengaitkan beberapa mata pelajaran sehingga dapat memberikan pengalaman bermakna kepada murid. Tema adalah pokok pikiran atau gagasan pokok yang menjadi pokok pembicaraan" Poerwadaminta dalam Majid (2014: 80). Melalui pembelajaran tematik peserta didik dapat memperoleh pengalaman bermakna yang berarti siswa bukan hanya belajar atau mengetahui materi saja namun lebih mendalam kepada konsepkonsep dari materi yang dipelajari. Jadi siswa akan lebih paham dan tidak mudah lupa jika akan materi yang sudah dipelajari.

Keberhasilan dalam belajar bukan hanya bergantung pada siswa saja namun peran guru juga sangat penting terhadap hasil belajar siswa. Salah satu penunjang keberhasilan dengan menerapkan metode, model, atau strategi pembelajaran. Namun dalam pembelajaran media pembelajaran juga diperlukan dalam proses belajar mengajar. Menurut Djamarah (2010:120) kata "media" berasal dari bahasa latindan merupakan bentuk jamak dari kata "medium", yang secara harfiah berarti "perantara atau pengantar".

Kustandi dan Bambang (2013: 9) mengatakan "media pembelajaran adalah alat yang dapat membantu proses belajar mengajar dan berfungsi untuk memperjelas makna pesan yang disampaikan, sehingga dapat mencapai tujuan pembelajaran dengan lebih baik dan sempurna". Karena fungsi utama media pembelajaran dapat membantu guru dalam penyampaian materi dan dapat membantu siswa mempermudah memahami materi. Jadi kreatifitas guru sangat diperlukan dalam mendidik dan membuat media pembelajaran untuk menunjang proses belajar mengajar di kelas. Media pembelajaran juga dapat membantu menciptakan interaksi antara siswa dan guru, sehingga tujuan pembelajaran dapat tercapai.

Menurut hasil observasi terhadap guru kelas tiga di SD N Peterongan mengatakan bahwa ada beberapa media yang sering digunakan di SDN Peterongan, seperti LCD, tanaman, dan gambar-gambar, namun media-media tersebut sangat terbatas dan belum cukup untuk meningkatkan minat belajar siswa dan membaca siswa. Minat belajar dan membaca siswa yang rendah membuat guru kesulitan dalam mengajar, karena pemahaman menjadi berkurang. Sehingga didapatkan hasil bahwa kegiatan belajar mengajar di kelas menjadi kurang kondusif.

Melihat fakta yang dipaparkan diatas, peneliti membuat inovasi yang dapat meningkatkan keaktifan dan minat baca siswa khususnya pada kelas tiga. Sesuatu yang baru tersebut yaitu dengan membuat media pembelajaran untuk meningkatkan keaktifan siswa dan minat membaca siswa dalam pembelajaran. Maka dari itu, peneliti bermaksud mengembangkan media Big Book sebagai media untuk mendukung kegiatan pembelajaran di kelas III Sekolah Dasar.

Big Book menurut Sulaiman (2017: 193) adalah buku bacaan yang memiliki ukuran, tulisan, dan gambar yang besar. Big Book berkarakteristik khusus yang dibesarkan, baik teks maupun gambarnya, sehingga memungkinkan terjadinya kegiatan membaca bersama antara guru dan murid. Big Book bagi pembaca pemula menunjukkan guru bagaimana cara menggunakan Big Book agar meningkatkan pengalaman membaca nyaring, kesalahan, dan kebenaran dari tulisan dan ilustrasi yang berukuran besar, ide-ide untuk menampilkan buku (tampilan kemasan buku), serta kegiatan menggunakan buku besar.

Buku Sumber untuk Dosen LPTK (2014) dalam Anggraeni (2016: 87) menjelaskan bahwa Big Book adalah buku bacaan yang memiliki ukuran, tulisan, dan gambar yang besar. Ukuran Big Book bisa beragam, misalnya ukuran A3, A4, A5, atau seukuran koran. Ukuran Big Book harus mempertimbangkan segi keterbacaan seluruh siswa di kelas.

Big Book merupakan sebuah media yang memiliki karakteristik khusus yang dibesarkan, baik teks maupun gambarnya, serta memiliki karakteristik khusus dalam segi bentuk gambar, warna. Agar dalam proses pembelajaran, di dalamnya terjadi kegiatan membaca bersama (shared reading) antara guru dan murid. Dalam media Big Book ini, di dalamnya memiliki karakteristik khusus, seperti penuh dengan warna-warni, gambar yang menarik (Gunawan, 2015) dalam Kiromi \& Fauziah (2016: 50)

Berdasarkan uraian yang telah dijabarkan, maka peneliti perlu melakukan pengembangan media Big Book pada tema Kewajiban dan Hakku, subtema Kewajiban dan Hakku sebagai Warga Negara siswa kelas III Sekolah Dasar. Pengembangan media ini diharapkan dapat membantu meningkatkan minat baca siswa dan minat belajar siswa sehingga mempermudah guru dalam menyampaikan pembelajaran tematik terutama pada tema Kewajiban dan Hakku, subtema Kewajiban dan Hakku sebagai Warga Negara di kelas III agar lebih efektif, menyenangkan, dan dapat meningkatkan keaktifan dan minat membaca peserta didik. 


\section{METODE PENELITIAN}

Jenis penilitian yang digunakan oleh peneliti adalah penelitian dan pengembangan (Research and Development). Menurut Sugiyono (2017: 407) "Metode penelitian dan pengembangan atau dalam Bahasa Inggrisnya Reasearch and Development adalah metode penelitian yang digunakan untuk menghasilkan produk tertentu, dan menguji keefektifan produk tersebut". Penelitian pengembangan ini, peneliti mengacu pada model penelitian dan pengembangan $(R \& D)$ menurut Sugiyono tahap pengembangan model penelitian dan pengembangan menggunakan alur berfikir, antara lain: (1) potensi dan masalah, (2) pengumpulan data, (3) desain produk, (4) validasi desain, (5) revisi desain, (6) uji coba produk, (7) revisi produk, (8) uji coba pemakaian, (9) revisi produk, (10) produksi massal.

Berdasarkan uraian tersebut peneliti memilih jenis penelitian pengembangan (Research and Development) karena peneliti mengembangkan sebuah media Big Book yang akan dikembangkan sebagai wujud media Big Book dengan inovasi baru namun dengan melalui tahap pengujian terlebih dahulu. Adapun langkah-langkah penelitian pengembangan yang dilakukan oleh peneliti adalah sebagai berikut: Potensi dan Masalah, Pengumpulan Informasi, Desain Produk, Validasi Desain, Perbaikan Desain, Uji Coba Produk. Peneliti hanya sampai langkah ke enam karena keterbatasan waktu dan biaya.

Subyek penelitian adalah seluruh siswa kelas IIIA, IIIB, IIIC SDN Peterongan yang berjumlah 28 siswa pada kelas IIIA, 32 siswa pada kelas IIIB, dan 28 siswa pada kelas IIIC.Analisis data yang digunakan dalam penelitian ini yaitu analisis data kualitatif dan analisis data kuantitatif. Data kulitatif dalam penelitian ini yaitu berupa komentar dan saran perbaikan dari ahli media dan ahli materi pembelajaran. Data kuantitatif dalam penelitian ini berupa skor penilaian ahli media, ahli materi, respon guru dan siswa. Kedua data tersebut didapat dari pengisian angket. Data yang sudah terkumpul dianalisis dengan cara menghitung skor yang diperoleh. Analisis skor yang digunakan yaitu analisis deskriptif yang dianalisis menggunakan langkah-langkah sebagai berikut: Penilaian angket kevalidanMenganalisis dari lembar angket dengan skala Likert berbentuk Checklist (?) dengan langkah sebagai berikut: (a) Peneliti menghitung skorsing setiap jawaban; (b) Menghitung jumlah skor yang diperoleh dari penelitian; (c) Menjumlahkan skor ideal yang diperoleh untuk seluruh item; (d) Membagi jumlah skor total dengan skor ideal; (e) Kemudian dikali 100\%.

$$
\text { presentase }=\frac{\text { skor total }}{\text { skor } \text { ideal }} \times 100 \%
$$

Dari presentase yang telah diperoleh kemudian ditransformasikan kedalam kalimat yang bersifat kuantitatif. Untuk menentukan kriteria dilakukan dengan cara yang dikemukakan Arikunto (2010: 44):

Tabel 1. Kriteria Skor Dikemukakan Arikunto

\begin{tabular}{ccc}
\hline No. & Interval (\%) & Kriteria \\
\hline 1. & $81-100$ & Sangat Baik \\
2. & $61-80$ & Baik \\
3. & $41-60$ & Cukup \\
4. & $21-40$ & Kurang \\
5. & $0-20$ & Kurang Sekali \\
\hline
\end{tabular}

Berdasarkan tabel 3.1 dijelaskan bahwa dalam menghitung penilaian angket validitas diperlukan rumus presentase yang kemudian dapat dilihat nilainya melalui interval dan kriteria kualitatif. Apakah media yang dibuat peneliti sangat tidak layak atau sangat layak untuk digunakan. Penilaian angket kepraktisan, hasil penilaian respon guru terhadap media pembelajaran Big Book untuk menganalisis data dari lembar angket tanggapan guru dengan skala Likert bentuk checklist (?) dilakukan dengan perhitungan yang sama dengan cara penilaian pada angket kevalidan.Hasil penilaian tanggapan siswa terhadap media pembelajaran Big Book dengan skala Guttman yang berupa "Ya-Tidak" diubah menjadi angka, dapat dilihat pada tabel 2 . 
Tabel 2. Penskoran Angket Tanggapan Siswa

\begin{tabular}{cc}
\hline Respon Siswa & Skor \\
\hline Ya & 1 \\
Tidak & 0 \\
\hline
\end{tabular}

Data kuantitatif yang terkumpul selanjutnya dianalisis dengan skala likert. Persentase tersebut menunjukkan tingkat keidealan media pembelajaran Big Book berdasarkan penilaian respon guru dan siswa kelas III SD Negeri Peterongan Semarang.

Berdasarkan penilaian kedua angket tersebut peneliti dikatakan berhasil apabila sesuai dengan indikator yang diharapkan. Dapat dikatakan valid dan praktis apabila presentase dari hasil ahli media dan ahli materi berada pada rentang 61-80\% dengan kriteria "baik".

\section{ANALISIS DAN PEMBAHASAN}

Media pembelajaran Big Book dikembangkan peneliti berdasarkan penelitian dan pengembangan (Research and Development). Peneliti menggunakan desain pengembangan yang di kemukakan oleh Sugiyono yang terdiri dari beberapa langkah antara lain: (1) potensi dan masalah, (2) pengumpulan data, (3) desain produk, (4) validasi desain, (5) revisi desain, (6) uji coba produk, (7) revisi produk, (8) uji coba pemakaian, (9) revisi produk, (10) produksi massal.

Tahap pertama yang dibutuhkan dalam melakukan penelitian adalah mengetahui apa yang dibutuhkan oleh guru dan siswa dalam pembelajaran. Maka dari itu dibutuhkan observasi dan memberikan angket kebutuhan kepada siswa dan guru. Peneliti melakukan observasi di SDN Peterongan Kota Semarang pada kelas III yang berjumlah tiga kelas yaitu kelas IIIA, IIIB, dan IIIC.

Selain melakukan observasi peneliti juga melakukan wawancara dan memberikan angket kebutuhan untuk siswa dan guru guna untuk mengetahui kebutuhan yang dibutuhkan oleh siswa dan guru terkait dengan media pembelajaran di kelas III. Untuk penelitian pengembangan ini, peneliti mengacu pada model penelitian dan pengembangan $(R \& D)$ menurut Sugiyono.

Media pembelajaran Big Book tematik merupakan suatu alternatif penggunaan media pembelajaran tematik yang akan membantu peserta didik dalam memahami materi pada tema 4 kewajiban dan hakku subtema 4 kewajiban dan hakku sebagai warga negara dan membantu guru untuk menyampaikan pembelajaran di kelas. Kelayakan media ini dapat dilihat dari hasil validasi ahli media, hasil validasi ahli materi, hasil angket repon siswa dan hasil angket respon guru kelas.

Berikut adalah penjelasan dari modifikasi langkah pengembangan peneliti :

1. Potensi dan Masalah

Peneliti mencoba mencari kemampuan yang dimiliki oleh siswa dan guru. Kemudian peneliti juga mencari permasalahan-permasalahan yang ada dalam proses pembelajaran, sehingga peneliti mengetahui apa yang harus dilakukan untuk mengatasi permasalahan yang ada.

2. Pengumpulan Informasi

Peneliti menemukan potensi dan masalah yang diambil dari hasil angket kebutuhan siswa dan guru serta wawancara guru kelas III SD Negeri Peterongan untuk mengetahui permasalahan yang ada serta menyelesaikan permasalahan tersebut dengan media pembelajaran Big Book.

3. Desain Produk

Peneliti memulai pembuatan Big Book dengan membuat konsep terlebih dahulu. Setelah konsep jadi, peneliti melanjutkan mendesain konsep tersebut menggunakan aplikasi power point. Lalu, peneliti mencetak menggunakan kertas artcartoon 310 dengan ukuran A3. Setelah melakukan percetakan, maka peneliti melakukan pemotongan-pemotongan gambar lalu menempelkannya pada buku. Tahap terakhir yaitu menjilid buku dengan menggunakan ring dengan konsep buku ini dibuat seperti kalender duduk yang dapat berdiri atau digunakan secara biasa.

4. Validasi Desain

Peneliti melakukan validasi desain dengan menggunakan media Big Book pada ahli media dan materi dan membagikan angket validasi ahli media dan materi untuk mengetahui tingkat kevalidan dan kepraktisan media Big Book. Berikut adalah penjelasannya:

\section{Hasil Validasi Ahli Media}

Tahap validasi ahli media bertujuan untuk mengetahui kelayakan pembuatan produk media pembelajaran Big Book sebelum dilakukan uji coba lapanga awal. Pada tahap ini, peneliti memilih tiga 
validator sebagai validator ahli media yang merupakan dosen Pendidikan Guru Sekolah Dasar Universitas PGRI Semarang yaitu bapak Singgih Adhi Prasetyo, S. Sn., M.Pd, bapak Sukamto, S.Pd., M.Hum, dan ibu Anggun Dwi Setya Putri S.Pd., M.Pd. Validasi media dilakukan dengan memberikan lembar angket validasi ahli media. Berikut adalah hasil analisis penliaian dari ahli media tahap pertama pada tabel 3.

Tabel 3. Hasil Validasi Ahli Materi Tahap 1

\begin{tabular}{|c|c|c|c|}
\hline No & Ahli Media & Presentasi Keidealan & Kriteria \\
\hline 1 & $\begin{array}{l}\text { Singgih Adhi Prasetyo, } \\
\text { S.Sn., M.Pd. }\end{array}$ & $85 \%$ & Sangat Baik \\
\hline 2 & Sukamto, S.Pd., M.Pd. & $85 \%$ & Sangat Baik \\
\hline 3 & $\begin{array}{l}\text { Anggun Dwi Setya } \\
\text { Putri, S.Pd., M.Pd }\end{array}$ & $73,33 \%$ & Baik \\
\hline
\end{tabular}

Berdasarkan Tabel 3 maka dapat diperoleh hasil rata-rata presentase keidealan penilaian ahli media tahap pertama sebesar 83,55\% sehingga media Big Book termasuk dalam kriteria "sangat baik". Namun, peneliti masih melakukan validasi tahap kedua untuk memperbaiki produk, sehingga peneliti melakukan revisi pada media Big Book. Revisi berupa memperbaiki background cover belakang dan kertas cover biasa menjadi hard cover.

Tabel 4. Hasil Validasi Ahli Materi Tahap 2

\begin{tabular}{clcc}
\hline No & \multicolumn{1}{c}{ Ahli Media } & Presentasi Keidealan & Kriteria \\
\hline 1 & Sukamto, S.Pd., M.Pd. & $85 \%$ & Sangat Baik \\
2 & Anggun Dwi Setya & $73,33 \%$ & Baik \\
Rata-rata & Putri, S.Pd., M.Pd & $91,33 \%$ & Sangat Baik \\
\hline
\end{tabular}

Berdasarkan Tabel 4 maka dapat diperoleh hasil rata-rata presentase keidealan penilaian ahli media tahap pertama sebesar 91,33\% sehingga media Big Book termasuk dalam kriteria "sangat baik" dan dapat digunakan pada pembelajaran di sekolah.

\section{Hasil Respon Siswa}

Media Big Book merupakan suatu hal baru yang diperoleh siswa. Hasil angket respon siswa bertujuan untuk mengetahui respon siswa terhadap keberterimaan media Big Book pada uji coba lapangan awal dengan dilakukan pengisian angket respon siswa kelas III di SDN Peterongan Semarang dan diperoleh hasil sebagai berikut:

Tabel 5. Hasil Respon Siswa

\begin{tabular}{crcc}
\hline No & Kelas & Presentasi Keidealan & Kriteria \\
\hline 1. & IIIA & $97,6 \%$ & Sangat Baik \\
2. & IIIB & $100 \%$ & Sangat Baik \\
3. & IIIC & $100 \%$ & Sangat Baik \\
\multicolumn{2}{c}{ Rata-rata } & $99,2 \%$ & Sangat Baik \\
\hline
\end{tabular}

Berdasarkan Tabel 5 maka dapat diperoleh hasil rata-rata presentase keidealan penilaian ahli media tahap kedua sebesar 99,2\% sehingga media Big Book termasuk dalam kriteria "sangat baik".

\section{Hasil Respon Guru}

Hasil angket respon guru kelas bertujuan untuk mengetahui respon guru kelas terhadap kelayakan media Big Book pada uji coba lapangan awal dengan dilakukan pengisian angket respon guru kelas IIIA, IIIB dan IIIC di SDN Peterongan Semarang serta diperoleh hasil sebagai berikut: 
Tabel 6. Hasil Respon Guru

\begin{tabular}{cccc}
\hline No & Kelas & Presentasi Keidealan & Kriteria \\
\hline 1. & IIIA & $98 \%$ & Sangat Baik \\
2. & IIIB & $88 \%$ & Sangat Baik \\
3. & IIIC & $80 \%$ & Baik \\
& Rata-rata & $88,6 \%$ & Sangat Baik \\
\hline
\end{tabular}

Berdasarkan Tabel 6, maka dapat diperoleh hasil rata-rata presentase keidealan penilaian ahli media tahap kedua sebesar 88,6\% sehingga media Big Book termasuk dalam kriteria "sangat baik" dan dapat digunakan pada pembelajaran di sekolah.

\section{KESIMPULAN}

Berdasarkan dari hasil penelitian dan pengembangan media Big Book, simpulan yang dapat diambil dari penelitian dan pengembangan ini adalah Media Big Book valid digunakan pada tema kewajiban dan hakku subtema kewajiban dan hakku sebagai warga negara kelas III sekolah dasar dengan mendapat skor rata-rata presentase keidealan dari ahli media sebesar 91,34\% dengan kriteria "sangat baik" dan dari skor rata-rata presentase keidealan ahli materi sebesar 92,80\% dengan kriteria "sangat baik". Media Big Book praktis digunakan pada tema keluargaku kelas III sekolah dasar dengan mendapat skor rata-rata presentase keidealan hasil respon guru sebesar 88,\% dengan kriteria "sangat baik" dan dari skor rata-rata presentase keidealan hasil respon siswa sebesar 99,2\% dengan kriteria "sangat baik". Dari semua presentase media pembelajaran Big Book mendapat kriteria "sangat baik" yang memiliki arti bahwa media Big Book layak digunakan sebagai media pembelajaran kelas III pada tema kewajiban dan hakku subtema kewajiban dan hakku sebagai warga negara.

Dari hasil penelitian, maka saran yang dapat diajukan adalah sebagai berikut : 1. Bagi guru, penggunaan media dalam pembelajaran sebaiknya diperlukan guna membantu guru dalam menyampaikan materi kepada siswa. Dengan penggunaan media, konsep materi pembelajaran yang masih abstrak akan lebih mudah dipahami oleh siswa dan pembelajaran akan berlangsung lebih menarik dan menyenangkan. Sehingga minat siswa dalam mengikuti pembelajaran semakin bertambah. 2. Bagi sekolah, pihak sekolah sebaiknya memberi fasilitas terhadap guru yang memiliki kreativitas dalam mengembangkan sebuah media pembelajaran untuk menunjang kebutuhan siswa dalam pembelajaran. 3 . Bagi peneliti, peneliti menyadari bahwa penelitian dan pengembangan ini belum sempurna, maka diharapkan dilakukan penelitian pengembangan selanjutnya di kemudian hari guna menyempurnakan penelitian ini dan menjadi produk baru dalam penelitian pengembangan tentang media pembelajaran.

\section{DAFTAR PUSTAKA}

Anggraeni, Krisna. 2016. “Efektivitas Metode Steinberg Dengan Media Big Book Terhadap Keterampilan Membaca Nyaring". http://www.unma.ac.id/jurnal/index.php/CP/article/view/322

Arikunto, Suharsimi. 2010. Manajemen Penelitian. Jakarta: Rineka Cipta.

Djamarah, Syaiful Bahri dan Aswan Zain. 2010. Strategi Belajar Mengajar. Jakarta: PT Rineka Cipta.

Fitriani, Tika N. dan Aminin, Zainul. 2013. “Pengaruh Penggunaan Media Buku Besar (Big Book) Terhadap Kemampuan Membaca Permulaan Anak Kelompok B Di Tk Qoshrul Ubudiyah Surabaya".http://jurnalmahasiswa.unesa.ac.id/index.php/paudteratai/article/view/2399

Gunawan, D. (2015). Sekali lagi tentang big book. Diambil pada tanggal 5 April 2015, dari http://www.kompasiana.com/dedygun awanhutajulu.

Hurlock, EB. (2002). Perkembangan anak. Jilid 1. Jakarta: Erlangga

Kemendiknas. (2012). Pedoman pendidikan karakter pada anak usia dini. Jakarta

Kustandi, Cecep dan Bambang Sutjipto. 2013. Media Pembelajaran Manual dan Digital. Bogor: Ghalia Indonesia. 
Latif, M., Zulkhairina., Zubaidah, R., \& Afandi, M. (2013). Orientasi baru pendidikan anak usia dini: Teori dan aplikasi. Jakarta: Prenada Media.

Majid, Abdul. 2014. Pembelajaran Tematik Terpadu. Bandung: PT Remaja Rosdakarya.

Putra, Nusa. (2013). Research \& development penelitian dan pengembangan : Suatu Pengantar. Jakarta : Rajawali Pers

Sugiyono. 2017. Metode Penelitian Pendidikan: Kuantitatif,Kualitatif, RnD. Bandung: Alfabeta.

Sukmadinata, Nana Syaodih. 2016. Metode Penelitian Pendidikan. Bandung: PT Remaja Rosdakarya.

Sulaiman. 2017. "Pengaruh Penggunaan Media Big Book Dalam Pembelajaran Terhadap Keterampilan Literasi Siswa Kelas Awal Madrasah Ibtidaiyah Negeri Banta-Bantaeng Makassar". http://journal.uinalauddin.ac.id/index.php/klm/article/view/4486/4103

Susanti, Reni Indriani. (2017). Penggunaan Media Bigbook untuk Meningkatkan Hasil Belajar Membaca Bahasa Inggris Kelas III. Diakses dari lama web tanggal 28 mei 2018 dari: http://eprints.umm.ac.id/35523/.

Susanto, Ahmad. (2013). Teori Belajar Dan Pembelajaran Di Sekolah Dasar. Jakarta: Prenada Media Group

Surya, Mohamad. (2015). Psikologi Guru (Konsep Dan Aplikasi Dari Guru, Untuk Guru). Bandung: Alfabeta. 